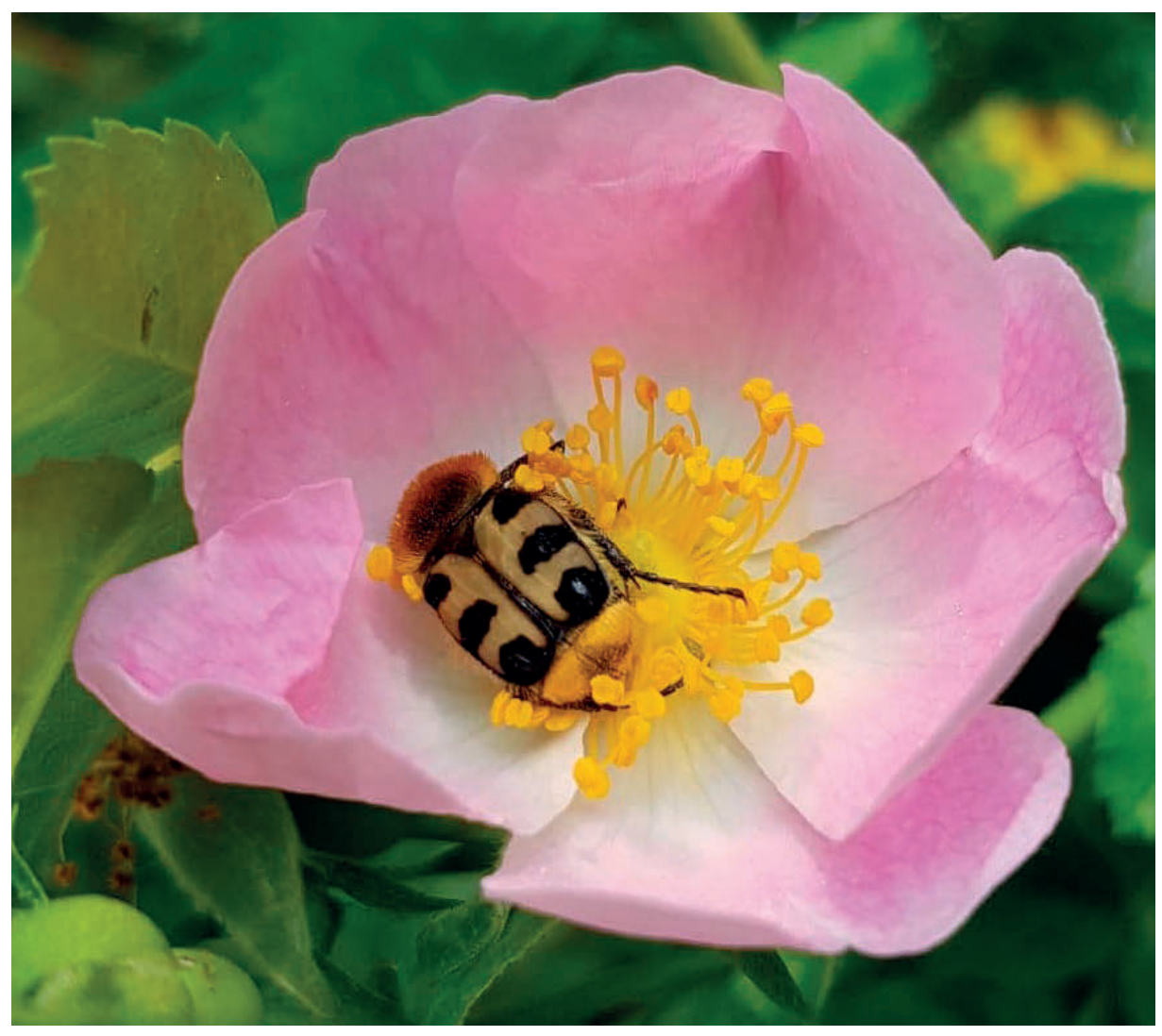




\section{LILLE HUMLEBILLE}

\section{TOBIAS SANDFELD JENSEN}

Jeg er lille humlebille, den smukkeste af biller! Min store familie hedder torbisterne. Vi er kompakte med vifteformede antenner og lever for det meste i lort. Men ikke MIG! Jeg lever i smukke blomsters pollen! Gult og lækkert som MIG! Mit latinske navn er Trichius rosaceus - mmmh rosaceus. Det smager nærmest af sommer. Sommer, sommer, sommer, sommer! De siger, at jeg er billernes svar på Peter Plys, skønt jeg ikke ved, hvem denne Peter er, men han må være smuk og dejlig som MIG! Jeg er stor, gul, vamset og venlig. Min fine flotte pels er vidunderlig som den sommerdag, jeg klækkede fra mit bo i de gamle jernbanesveller. Mine unger lever af gammelt dødt træ. Ikke grimme modbydelige sveller, der smager grimt! Men lækkert gammelt velsmagende træ, som ligger på en dejlig varm plet i en skovlysning. Men dem findes der ikke mange af i skoven! Så jeg er rykket ind i byen til de gamle jernbanesveller, som ligger lyst og lunt. Man kunne kalde MIG en flygtning! Jeg kommer også sydfra. Fra varmen, hvor solen den danser og træerne bliver gamle. Jeg bliver ikke gammel. Kun en enkelt sommer, men hvilken sommer! Mæsker MIG i brombærrenes skriggule pollen. Soler MIG i min egen skønhed. Formerer MIG i et kort meningsfuldt øjeblik. Lader mine gener strømme videre i evighedens endeligt. Store kulisser skifter scene. Efterkommere på efterkommere på efterkommere i et stort livsbekræftende virvar uden retning. Og der, lige der, vil jeg dø en salig død i en brombærblomst midt i byens larm. En sky glider for solen, og jeg forsvinder, uden at nogle bemærker det. Uden at nogle stopper op. Uden at en tåre forlader en kind eller et suk slipper et par læber. Uden det mindste ophold i tid, ikke et sekund bliver spildt, og kloden roterer videre på sin rejse i det endeløse univers.

Meningen med livet er et kort øjeblik, hvor vi fortaber os selv i livets mirakel. Thi, naturen er riget og magten og æren i evighed! 